\title{
PROGRAMME
}

\section{CANADIAN ANAESTHETISTS' SOCIETY ANNUAL MEETING}

SHERATON-MT. ROYAL HOTEL, MONTREAL, QUEBEC, JUNE 25-30, 1967

\section{Scientific Programme}

Twenty minutes is allowed for presentation of a paper and speakers must keep within this time. Five minutes is allowed to named discussants with five minutes for questions from the floor. Guest speakers are allotted thirty minutes. Papers will be presented in the language in which the titles are given.

Monday, June 26, 1967

8:00 A.M. Registration and opening of exhibits

8:30 A.M. Scientific Session

chamman: The President, Dr. I. E. Purkis, Halifax, N.S.

8:35 A.M. "The Interaction of Drugs with Particular Reference to Anaesthetic Practice"

Leonard C. Jenkins, Horace B. Graves, U.B.C. and Vancouver General Hospital DISCUSSOR: Dr. J. McIntyre, Edmonton

9:00 A.M. "Prévention et traitement des réactions émotionnelles après chirurgie à cour ouvert en salle de soins intensifs"

André McClish, Hôpital Laval, Quebec City Discussor: Dr. M. Keeri-Szanto, Montreal

9:30 A.M. "The Use of Fentanyl in the Operative and Postoperative Period" J. McIntyre and J. Miller, University Hospital, Edmonton, Alberta Discussor: Dr. Eric Nilsson, Lund, Sweden

10:00 A.M. Coffee and visit to exhibits

10:30 A.M. GUEST SPEAKER: Dr. André Soetens, Antwerp, Belgium

"Le métabolisme de l'eau et des électrolytes en neurologie et en neurochirurgie"

11:00 A.M. Panel Discussion: "Shock: Concepts and Treatment"

Chatrman: Professor Gordon Wyant, University of Saskatchewan MEMBers: Dr. André Soetens, Antwerp, Belgium, Dr. Lloyd McLean, Dept. of Experimental Surgery, McGill University, Dr. Don Finlayson, St. Michael's Hospital and University of Toronto

2:15 P.M. Canadian Standards Association (Committee on Anaesthetic Equipment)

Dr. Gordon Wyant 
Tuesday, June 27, 1967

8:00 A.M. Registration and opening of exhibits

Scientific Session

Ghamman: Dr. Max Minuck, Vice-President, Winnipeg

8:00 A.M. "Reflex Mechanisms of Postural Vasoconstriction"

A. Galindo, Assistant Professor of Anaesthesia, McGill University DIScussor: Dr. W. E. Spoerel, London, Ontario

8:30 A.M. "Oxygen Levels and Haemodynamics during Anaesthesia with Nitrous Oxide, Thiopental, and Curare"

R. A. Theye and Charles J. Restall, Section of Anaesthesiology, Mayo Clinic and Mayo Graduate School of Medicine, Rochester, Minnesota Discussor: Dr. H. B. Fairley, Toronto

9:00 A.M. "Neuroendocrine and Metabolic Effects of General Anaesthesia Associated with Acute Hypoxia and Acute Hypercapnia"

Allen B. Dobkin, Peter H. Byles, John F. Neville, Jr., and Benjamin Africa, Upstate Medical Centre, State University of New York, Syracuse

DISCUSSOR: Dr. Gordon Wyant, Saskatoon

9:30 A.M. "Experimental Central Nervous System Studies Related to Anaesthesia: IV. The Possible Role of the Caudate Nucleus in Barbiturate Anaesthesia"

K. M. Leighton, R. D. Jack, M. Chaplin, L. C. Jenkins, University of British Columbia

DIscusson: Professor Guy Vourch, Paris, France

10:00 A.M. Coffee and visits to exhibits

10:30 A.M. GUEST SPEAkER: Professor Guy Vourch, Department of Anaesthesiology, Faculty of Medicine, Paris, France

"Study of the Action of Drugs on the Electrical Activity of the Brain and Thalmus: Clinical Implication"

11:00 A.M. "Anaesthesia in Canada-1847-1967"

Harold R. Griffith, F.R.C.P.(C), F.F.A.R.C.S., F.A.C.A., Professor Emeritus, McGill University, André Jacques, F.R.C.P.(C), F.F.A.R.C.S., Laval University, Quebec

11:30 A.M. Panel Discussion: "Selection and Education of Residents" Chairman: Professor R. A. Gordon, University of Toronto MEMRERS: Professor James Parkhouse, University of Manitoba, Professor S. L. Vandewater, Queen's University, Professor Lester McCallum, Department of Medicine, McGill University, Professor Eric Nilsson, University of Lund, Sweden

6:00 P.M. Degustation des vins et fromages, University Centre Ball Room, 3480 McTavish Street, courtesy of Hoffmann-La Roche Limited 
Wednesday, June 28, 1967

8:00 A.M. Registration and opening of exhibits

Scientific Session

chamman: Professor R. G. B. Gilbert, McGill University

\section{Resments' Programme}

Sponsor: Ayerst Laboratories-3 Prizes totalling $\$ 1,000.00$

Judges: Dr. H. Churchill-Davidson, London, England, Dr. Eric Nilsson, Lund, Sweden, Dr. André Soetens, Antwerp, Belgium, Dr. Rudolph Frey, Mainz, W. Germany, Dr. Guy Vourch, Paris, France

8:00 A.M. "Respiratory Unit Management of Acute Head Injury: A Retrospective Study"

Dr. G. H. Hodgson

8:25 A.M. "Toxémie de la Grossesse et Anesthésie"

Dr. Oswald H. Hyppolite

8:50 A.M. "The Measurement of Functional Residual Capacity during Intermittent Positive Pressure Ventilation"

Dr. Alan K. Laws

9:15 A.M. "Atypical Cholinesterase Activity: A Review and the Presentation of Two Cases"

Dr. Dale L. Zoerb

9:40 A.M. "The Usefulness of Central Venous Blood Samples as an Index of Arterial Acid-Base Balance and Oxygenation"

Dr. P. R. Ramachandran

10:05 A.M. "A Review of the Causes of Postoperative Hypoxia"

Dr. G. R. Sellery

10:30 A.M. "Fluid Therapy during Surgery"

Dr. M. G. Viguera

10:35 A.M. Coffee break and visits to exhibits

11:20 A.M. "Recent Studies in the Mode of Action of Epidural Analgesia" [not included in the competitive programme]

Dr. Michael F. Burfoot and Dr. P. R. Bromage

11:40 A.M. "Acute Carbon Monoxide Poisoning: A Case Report" [not included in the competitive programme]

Drs. Gary L. Townsend and John B. Stetson, Indiana University Medical Centre

12:00 M. Annual Business Meeting, Canadian Anaesthetists' Society

Wednesday evening, June 28, 1967

7:00 P.M. Cocktail party, courtesy of Abbott Laboratories

8:00 P.M. Annual dinner and dance 


\section{Scientufic Programme}

Thursday, June 29, 1967

8:00 A.M. Registration and opening of exhibits Scientific Session

chamran: Dr. Léon Longtin, Montreal

8:00 A.M. "Current Concepts of Spinal Anaesthesia"

Peere Lund, Johnstown, Pennsylvania, University of Pittsburgh Discusson: Dr. Philip R. Bromage, Montreal

8:30 A.M. "Prolanest"

Bernard Paradis, Laval University, Quebec City Discussor: Dr. R. A. Gordon, Toronto

9:00 A.M. "Place du Propranolol intraveineux dans le traitement des arythmies rencontrées durant et après chirurgie cardiaque"

André McClish, Hôpital Laval, Quebec City Discussor: Dr. Alan W. Conn, Toronto

9:30 A.M. "Evaluation de l'humidité dans les circuits d'anesthésie"

R. Déry, J. J. Pelletier, André Jacques, M. Clavet, J. J. Houde, Hôtel-Dieu de Québec et Université Laval Discussor: Dr. Alan Noble, Montreal

10:00 A.M. Coffee and visits to exhibits (please note that all exhibits must be cleared by 2:00 P.M. today)

10:30 A.M. GUEST SPEAkger: Dr. Harry C. Churchill-Davidson, London, England "Some Problems in the Use of Muscle Relaxants"

11:00 A.M. Panel Discussion: "Relaxants: Physiology and Pharmacology" ChatRMan: Professor R. G. B. Gilbert, McGill University MEMbers: Dr. H. C. Churchill-Davidson, London, England, Professor Rudolph Frey, Mainz, W. Germany, Professor Kris Krnpevic, Research Department, McGill University, Professor Werner Kalow, Department of Pharmacology, University of Toronto

2:30 P.M. Meeting of New Council, 1967-1968 
Friday, June 30, 1967

8:00 A.M. Registration

Scientific Session

chamman: Professor S. L. Vandewater, Kingston, Ontario

8:00 A.M. "Anaesthesia in Primitive Conditions"

Eric Webb, Vancouver General Hospital, recently at University of Lagos, Nigeria Discusson: Dr. V. Fowler, Lagos, Nigeria

8:30 A.M. "Anaesthetic and Surgical Consideration for Partial Hepatectomy Using Portal and Systemic Hypotension"

John I. Davies, Abraham Kaplan, Alfred Heilbrunn, Veterans Administration Hospital, Kansas City, Missouri Duscusson: Dr. Abraham Kaplan, Kansas City, Missouri

9:00 A.M. GUEST SPEAKER: Professor Rudolph Frey, Mainz, West Germany "Resuscitation at the Place of Accident and during Transportation"

9:30 A.M. "Dose Response Studies with Aspirin" James Parkhouse, University of Manitoba Discusson: Professor W. Kalow, Toronto

10:00 A.M. Coffee

10:30 A.M. "Effect of Methoxyflurane Anesthesia on Intraocular Tension"

A. Schettini, Stewart E. Owre, Austin I. Fink, Long Island College Hospital, Brooklyn, New York DIscusson: Dr. Max Minuck, Winnipeg

11:00 A.M. Panel Discussion: "Neuroleptanalgesia: New Promise for Problem Patients"

Chatrman: Dr. M. Keeri-Szanto, University of Montreal MEMrers: Dr. Eric Nilsson, University of Lund, Sweden, Dr. G. Corssen, University Hospital, Ann Arbor, Dr. Brian Marshall, University of Toronto

"DEvII's ADVOcATE": Dr. Howard Zauder, Albert Einstein Medical Centre, New York

'Dr. Eric Nilsson is a guest speaker courtesy of Hoechst Pharmaceuticals and is incorporating his paper on "A Review of Neuroleptanalgesia" in the panel discussion. 